\title{
Multi Level Marketing dalam Tinjauan Hukum Islam (Studi Fatwa DSN-MUI NOMOR: 75/DSN-MUI/VII/2009 Tentang Pedoman Penjualan Langsung Berjenjang Syariah)
}

\author{
Luqman Nurhisam \\ Institut Agama Islam Negeri Kudus \\ luqman@iainkudus.ac.id
}

\begin{abstract}
The Multi Level Marketing (MLM) business is increasingly developing, and even shariabased MLM is emerging. Sharia-based companies are required to fulfill their promises or commitments. This is in accordance with the teachings of Islam, in reality, now many MLM companies have grown at home and abroad. Examples are Sunday Net, UFO BKB Sharia, Exer, Mitra Permata Haji, and K-Link Indonesia who carry out sharia principles and obtain halal certificates from DSN-MUI, as stated in Number: 75 / DSN-MUI / VII / 2009. The purpose of this study is to analyze the ability of the Multi Level Marketing mechanism by using an Islamic legal framework referring to the DSN-MUI Fatwa Number: 75 / DSN-MUI / VII / 2009. The research method used is library research, with descriptive-qualitative analysis. The results in this study indicate that Multi Level Marketing which has been practiced by the public as stated by DSN-MUI Number: 75 / DSN-MUI / VII / 2009 concerning Sharia Tiered Direct Selling Guidelines, the law is permissible, with reference to the traditions outlined previously that it could be used as a document or legal guide and all business activities that use a tiered sales guideline were required to fulfill various provisions as contained in the fatwa of DSN-MUI Number: 75 / DSN-MUI / VII / 2009. DSN-MUI uses these arguments as a basis in general, because there are no specific arguments related to Multi Level Marketing.

Keywords: Multi Level Marketing, MLM, DSN-MUI fatwa
\end{abstract}

\begin{abstract}
Abstrak
Bisnis Multi Level Marketing (MLM) kian hari makin berkembang, bahkan muncul MLM yang berbasis syari'ah. Perusahaan yang berbasis syari'ah diwajibkan memenuhi janji atau komitmennya. Hal ini sesuai dengan ajaran Islam, secara realitas, kini perusahan MLM sudah banyak tumbuh di dalam maupun luar negeri. Contohnya adalah Ahad Net, UFO BKB Syariah, Exer, Mitra Permata Haji, dan K-Link Indonesia yang menjalankan prinsip syari'ah dan memperoleh sertifikat halal dari DSN-MUI, sebagaimana yang difatwakan dalam Nomor: 75/DSN-MUI/VII/2009. Tujuan dari penelitian ini adalah untuk menganalisa kebolehan dari mekanisme Multi Level Marketing dengan menggunakan kerangka hukum Islam merujuk pada Fatwa DSN-MUI Nomor: 75/DSN-MUI/VII/2009. Metode penelitian yang digunakan adalah library research, dengan analisa deskriptif-kualitatif. Hasil dalam penelitian menunjukkan bahwa Multi Level Marketing yang mana telah dipraktekkan oleh masyarakat sebagaimana yang difatwakan oleh DSN-MUI Nomor: 75/DSN-MUI/VII/2009 tentang Pedoman Penjualan Langsung Berjenjang Syariah hukumnya adalah boleh, dengan merujuk kepada hadis-hadis yang diuraikan sebelumnya bahwasanya dapat dijadikan sebagai hujjah atau pedoman hukum dan segala kegiatan bisnis yang
\end{abstract}


Multi Level Marketing dalam Tinjauan Hukum Islam (Studi Fatwa DSNMUI NOMOR: 75/DSN-MUI/VII/2009 Tentang Pedoman Penjualan Langsung Berjenjang Syariah)

menggunakan pedoman penjualan berjenjang diharuskan memenuhi berbagai ketentuan-ketentuan sebagaimana yang terdapat dalam fatwa DSN-MUI Nomor: 75/DSN-MUI/VII/2009. DSN-MUI menggunakan dalil-dalil tersebut adalah sebagai landasan secara umum, karena tidak ada dalil yang spesifik terkait dengan Multi Level Marketing.

Kata kunci: Multi Level Marketing, MLM, fatwa DSN-MUI

\section{PENDAHULUAN}

Salah satu pola bisnis yang saat ini sangat marak dilakukan adalah bisnis dengan sistem Multi Level Marketing atau MLM yang merupakan salah satu cabang dari direct selling adalah salah satu sistem bisnis yang pemasaran produknya menggunakan member sebagai pembeli, konsumen, pemasar, promoter, dan sebagai distributor. Multi Level Marketing adalah pemasaran yang berjenjang banyak. Disebut multi level karena merupakan suatu organisasi distributor yang melaksanakan penjualan yang berjenjang banyak atau bertingkat-tingkat (Yusuf, 3). Disebut demikian, karena anggota kelompok tersebut semakin banyak, sehingga membentuk sebuah jaringan kerja (network) yang merupakan suatu sistem pemasaran dengan menggunakan jaringan kerja berupa sekumpulan banyak orang yang kerjanya melakukan pemasaran.

Bisnis MLM makin hari makin berkembang, bahkan muncul MLM yang berbasis syari'ah. Perusahaan yang berbasis syari'ah diwajibkan memenuhi janji atau komitmennya. Ini sesuai dengan ajaran Islam, secara realitas, kini perusahan MLM sudah banyak tumbuh di dalam maupun luar negeri. Contohnya adalah Ahad Net, UFO BKB Syariah, Exer, Mitra Permata Haji, dan K-Link Indonesia yang menjalankan prinsip syari'ah dan memperoleh sertifikat halal dari DSN-MUI. Sebagaimana yang difatwakan dalam Nomor: 75/DSN-MUI/VII/2009.

Dalam pembahasan makalah ini, penulis fokus kepada hadis-hadis yang menjadi dasar ditetapkannya MLM syariah sebagaimana yang telah dipraktekkan oleh masyarakat yang mana termasuk dalam Penjualan Langsung Berjenjang Syariah (PLBS).

\section{PEMBAHASAN}

\section{A. Studi Hadis}

\section{Teks Hadis}

$$
\text { عوف) مسلمون على شروطهم إلاّ شرطا حرّم حلالا أو أحلّ حر اما ...(رواه الترمذي عن عمرو بن }
$$

“...Kaum muslimin terikat dengan syarat-syarat mereka kecuali syaratsyarat yang mengharamkan yang halal atau menghalalkan yang haram..." (HR. Tirmidzi dari 'Amr bin 'Auf) 


\section{Status Hadis}

Dilihat dari segi sampai tidaknya hadis ini kepada Nabi, maka hadis ini termasuk hadis marfu'.

Menurut Imam Tirmidzi, bahwa hadis ini Hasan Shohih. As-Syaukani menghukuminya sebagai hadis Hasan.

\section{Teks Hadis}

$$
\text { لا ضرر و لا ضر ار (رواه ابن ماجه و الدارقطني و غير هما عن أبي سعيد الخدري) }
$$

“Tidak boleh membahayakan diri sendiri maupun orang lain." (HR. Ibnu Majah, Daruquthni, dan yang lain dari Abu Sa'id al-Khudri).

\section{Status Hadis}

Menurut Ibnu Rajab Al-Hanbali termasuk hadis Hasan. Ibnu Rojab menukil dari Ibnu Sholah mengatakan bahwa hadis ini adalah hadis hasan, karena beberapa sanad terkait hadis ini saling menguatkan satu dengan yang lainnya. Menurut Al-Hakim, sanadnya shohih, yang perawinya adalah perawi hadis di shohih Imam Muslim. Imam Nawawi mengatakan hadis ini hadis hasan karena jalur periwayatannya saling menguatkan satu dengan lainnya.

\section{Teks Hadis}

$$
\text { نهى رسول الله عليه وسلّم عن بيع الحصاة، وعن بيع الغرر (رواه الخمسة عن ابي هريرة) }
$$

"Nabi Saw. melarang jual beli dengan cara melempar batu dan jual beli gharar." (HR. Khomsah dari Abu Hurairah)

\section{Status Hadis}

Dari segi sampai tidaknya hadis ini kepada Nabi, maka hadis ini termasuk hadis marfu'. Sedangkan ditinjau dari segi kuantitas sanadnya, hadis ini diriwayatkan pleh lima orang, hadis ini adalah hadis masyhur. Hadis ini termasuk hadis shohih.

\section{Teks Hadis}

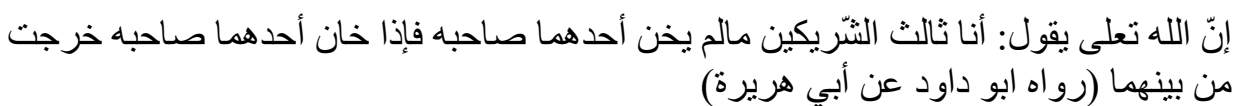

"Allah Swt. Berfirman: Aku adalah pihak ketiga dari dua orang yang bersyarikat selama satu pihak tidak mengkhianati pihak yang lain. Jika salah satu pihak telah berkhianat, Aku keluar dari mereka." (HR. Abu Dawud, yang dishohihkan oleh Al-Hakim, dari Abu Hurairah).

\section{Status Hadis}

Dilihat dari segi sampai tidaknya hadis ini kepada Nabi, maka hadis ini termasuk hadis marfu'. Hadis ini dikatakan shohih. 
Multi Level Marketing dalam Tinjauan Hukum Islam (Studi Fatwa DSNMUI NOMOR: 75/DSN-MUI/VII/2009 Tentang Pedoman Penjualan Langsung Berjenjang Syariah)

B. Multi Level Marketing Syariah (MLM Syariah) dalam Fatwa DSNMUI Nomor 75/DSN-MUI/VII/2009 Tentang Pedoman Penjualan Langsung Berjenjang Syariah

MLM adalah singkatan dari Multi Level Marketing. Menurut bahasa multi berarti banyak, level berarti jenjang atau tingkat, sedangkan marketing berarti pemasaran. Jadi multi level marketing adalah pemasaran yang berjenjang banyak.

Multi Level Marketing menurut Andrias Harefa, merupakan salah sau dari berbagai cara yang dapat dipilih oleh sebuah perusahaan atau pabrik untuk memasarkan atau mendistribusikan dan menjual produknya kepada pelanggan eceran dengan memberdayakan distributor independennya untuk melaksanakan tugas pemasaran, pendistribusian, dan penjualan produk melalui pengembangan armada pemasar, distributor dan penjual langsung secara mandiri (independen) tanpa campur tangan langsung pemerintah (Harefa, 1999).

Definisi lain tentang MLM dikemukakan oleh Benny Santoso, bahwa MLM hanyalah suatu metode bisnis alternative yang berhubungan dengan pemasaran dan distribusi. Perhatian utama dari MLM adalah menentukan cara terbaik untuk menjual produk dari satu perusahaan melalui inovasi bidang pemasaran dan distribusi. MLM hanya berkaitan dengan bagaimana bisa menjual suatu produk dengan lebih efisien dan efektif kepada pasar. MLM tergantung sepenuhnya pada kualitas dari produk yang dijual. Dengan kata lain, MLM seharusnya tidak akan keluar dari aturan-aturan yang ada pada bisnis umumnya (Santoso, 2003).

MLM adalah kegiatan untuk menjual produk yang dilakukan dalam bentuk Non Store (tidak menggunakan bangunan fisik berupa toko), dan penjualan dilakukan secara langsung (Direct Selling). Jadi ciri khas dari MLM adalah produk-produk MLM hanya bisa diperoleh di tempattempat tertentu dan produk tidak pada sembarang toko. Definisi ini dikemukakan oleh Singgih Santosa (Santoso, 2000). Dari berbagai definisi tersebut, dapat dinyatakan bahwa MLM merupakan suatu konsep penyaluran barang (produk/jasa tertentu) yang member kesempatan kepada para konsumen untuk terlibat sebagai penjual dan menikmati keuntungan dari garis kemitraannya atau sponsorisasi (Lubis, 2000).

Multi Level Marketing atau MLM adalah sebuah bisnis yang menggunakan konsep dengan memperpendek jalur pendistribusian dari produsen kepada konsumen. Sistem ini beda dengan sistem bisnis konvensional yang menggunakan beberapa distributor hingga sampai kepada konsumen. Dengan memperpendek jalur pendistribusian ini mengakibatkan menghemat biaya distribusi bahkan dapat ditekan lebih rendah. MLM tidak membutuhkan biaya promosi, karena promosi ditangani langsung oleh setiap member MLM dengan sistem berjenjang (pelevelan) sehingga dengan mempersingkat jalur pendistribusian ini 
dapat memangkas biaya pemasaran dan distribusi. Penghematan ini kemudian disalurkan kepada member yang berprestasi dalam menjalankan dan mengembangkan bisnis MLM, dalam bentuk komisi dan bonus, yang besarnya ditentukan sesuai dengan levelnya. Untuk mengembangkan bisnis MLM, para member diharuskan untuk merekrut orang lain untuk dijadikan downlinenya. Karena bisnis MLM dilakukan banyak tingkatan yang dikenal dengan upline yaitu orang yang merekrut, sedangkan downline adalah orang yang direkrut.

Secara realitas, kini perusahaan MLM sudah banyak tumbuh dan berkembang baik di dalam maupun luar negeri, bahkan di Indonesia sudah ada yang terang-terangan menyatakan bahwa MLM tersebut sesuai dengan syari'at dan mendapatkan sertifikasi halal dari Dewan Syariah Nasional Majelis Ulama Indonesia (DSN-MUI) sebagaimana yang dijelaskan dalam Fatwa Nomor 75/DSN-MUI/VII/ 2009 tentang Pedoman Penjualan Lansung Bejenjang Syariah (PLBS) yang termasuk di dalamnya adalah MLM sebagaimana yang telah dipraktikkan oleh masyarakat.

Dalam fatwa tersebut dijelaskan bahwa penjualan langsung berjenjang adalah cara penjualan barang atau jasa melalui jaringan pemasaran (network marketing) yang dilakukan oleh perorangan atau badan usaha kepada sejumlah perorangan atau badan usaha lainnya secara berturut-turut (DSN MUI, 2009). Dapat diketahui bahwa metode penjualan Multi Level Marketing termasuk daripada penjualan langsung berjenjang sebagaimana yang telah dipraktikkan oleh masyarakat. Sehingga dikeluarkannya fatwa oleh DSN-MUI tersebut adalah untuk memberikan pedoman kepada masyarakat secara jelas mengenai praktik Multi Level Marketing yang mana sesuai dengan koridor syari'ah sebagaimana diatur dalam Fatwa Tentang Pedoman Penjualan Langsung Berjenjang Syariah (PLBS).

\section{Ketentuan-Ketentuan Syari'ah dalam Multi Level Marketing Syariah}

Ada dua aspek untuk menilai apakah bisnis MLM itu sesuai dengan syari'ah atau tidak, yaitu 1) Aspek produk atau jasa yang dijual, 2) Sistem MLM itu sendiri (DSN, 2014).

\section{Aspek produk atau jasa yang dijual}

Dari aspek produk yang dijual, dalam hal ini objek dari MLM harus merupakan produk-produk yang halal dan jelas bukan produk yang dilarang oleh agama. Selain halal, objek juga harus bermanfaat dan dapat diserah terimakan serta mempunyai harga yang jelas. Oleh karena itu, meskipun MLM dikelola atau memiliki jaringan distribusi yang dijalankan oleh orang muslim namun apabila obyeknya tidak jelas bentuk, harga dan manfaatnya maka hal itu tidak sah.

\section{Sistem dari MLM itu sendiri}


Multi Level Marketing dalam Tinjauan Hukum Islam (Studi Fatwa DSNMUI NOMOR: 75/DSN-MUI/VII/2009 Tentang Pedoman Penjualan Langsung Berjenjang Syariah)

Pada dasarnya MLM yang berbasis syari'ah tidak jauh berbeda dengan MLM konvensional, namun yang membedakan adalah bahwa bentuk usaha atau jasa yang menjalankan usahanya harus memenuhi kriteria-kriteria sebagai berikut:

a. Sistem distribusi pendapatan haruslah dilakukan secara professional dan seimbang. Dengan kata lain, tidak terjadi eksploitasi antarsesama;

b. Apresiasi distributor, haruslah apresiasi yang sesuai dengan prinsip-prinsip Islam. Misalnya, tidak melakukan pemaksaan, tidak berdusta, jujur dan tidak merugikan pihak lain serta memiliki komitmen jiwa yang bagus (akhlakul karimah);

c. Penetapan harga kalaupun keuntungan (komisi dan bonus) yang akan diberikan kepada para anggota berasal dari keuntungan penjualan barang, bukan berarti harga barang yang dipasarkan harus tinggi. Hendaknya semakin besar jumlah anggota distributor, maka tingkat harga makin menurun yang pada akhirnya kaum muslim dapat merasakan sistem pemasaran tersebut;

d. Jenis produk yang ditawarkan haruslah produk yang benar-benar terjamin kehalalan dan kesuciannya, sehingga kaum muslim merasa aman untuk menggunakan dan mengkonsumsi produk yang dipasarkan.

Dalam Fatwa DSN-MUI Nomor: 75/DSN-MUI/VII/2009 tentang Pedoman Penjualan Langsung Berjenjang Syariah ada beberapa hal yang menjadi ketentuan sebagai penjualan langsung berjenjang syariah apabila memenuhi 12 ketentuan yang mana diuraikan sebagai berikut:

a. Ada objek transaksi riil yang diperjualbelikan berupa barang atau jasa;

b. Barang/jasa yang diperdagangkan bukan sesuatu yang diharamkan atau yang dipergunakan untuk sesuatu yang haram;

c. Transaksi dalam perdagangan tersebut tidak mengandung unsure gharar (penipuan), maysir (judi), dharar (bahaya), dzulm (aniaya/merugikan salah satu pihak, dan maksiat;

d. Tidak ada kenaikan harga/biaya yang berlebihan (excessive mark up) sehingga merugikan konsumen karena tidak sepadan dengan kualitas/manfaat yang diperoleh;

e. Komisi yang diberikan perusahaan kepada anggota harus berdasarkan pada prestasi kerja nyata yang terkait langsung dengan volume atau nilai hasil penjualan barang atau jasa dan harus menjadi pendapatan utama mitra usaha dalam PLBS (Penjualan Langsung Berjenjang Syariah);

f. Bonus yang diberikan oleh perusahaan kepada anggota (mitra usaha) harus jelas jumlahnya ketika dilakukan transaksi atau akad sesuai 
dengan target penjualan barang dan jasa yang ditetapkan oleh perusahaan;

g. Tidak boleh ada komisi/bonus secara pasif yang diperoleh secara reguler tanpa melakukan pembinaan dan atau penjualan barang dan jasa;

h. Pemberian komisi/bonus oleh perusahaan kepada anggota (mitra usaha) tidak menimbulkan ighra' (daya tarik luar biasa yang menyebabkan orang lalai terhadap kewajibannya demi melakukan hal-hal atau transaksi dalam rangka memperoleh bonus/komisi yang dijanjikan);

i. Tidak ada eksploitasi dan ketidakadilan dalam pembagian bonus antara anggota pertama dengan anggota berikutnya;

j. Sistem perekrutan keanggotaan, bentuk penghargaan dan acara seremonial yang dilakukan tidak mengandung unsur yang bertentangan dengan dengan akidah. Syari'ah dan akhlak mulia, seperti syirik, kultus, maksiat, dan lain sebagainya;

k. Setiap mitra usaha yang melakukan perekrutan keanggotaan berkewajiban melakukan pembinaan dan pengawasan kepada anggota yang direkrutnya;

1. Tidak melakukan kegiatan money game.

\section{Kontekstualisasi}

\section{PT. K-Link Indonesia}

PT. K-Link menjadi perusahaan Multi Level Marketing yang kelima setelah Ahad Net, UFO BKB Syariah, Exer, dan Mitra Pertama Mandiri yang telah memperoleh sertifikat MLM syariah dari Dewan Syariah Nasional Majelis Ulama Indonesia (DSN-MUI). K-Link dan perusahaan MLM lainnya memiliki Dewan Pengawas Syariah (DPS). DPS tersebut terdiri dari beberapa ulama yang memiliki kompetensi di bidang ilmu fikih dan ekonomi.

Penulis mencoba menganalisis apakah MLM yang dijalankan oleh PT. K-Link Indonesia sesuai dengan ketentuan-ketentuan yang ada dalam fatwa DSN-MUI Nomor: 75/DSN-MUI/VII/2009, yang mana terdapat 12 ketentuan yang harus dipenuhi agar dapat dikategorikan sebagai penjualan langsung berjenjang syariah.

1. Ada objek transaksi riil yang diperjualbelikan berupa barang atau jasa;

PT. K-Link memiliki berbagai macam produk supplemen makanan dan kesehatan yang diperjualbelikan oleh member-membernya maupun non membernya.

2. Barang/jasa yang diperdagangkan bukan sesuatu yang diharamkan atau yang dipergunakan untuk sesuatu yang haram; 
Multi Level Marketing dalam Tinjauan Hukum Islam (Studi Fatwa DSNMUI NOMOR: 75/DSN-MUI/VII/2009 Tentang Pedoman Penjualan Langsung Berjenjang Syariah)

Produk dari PT. K-Link sudah jelas kehalalannya yang mana murni terbuat dari tumbuh-tumbuhan dan madu. Yang mana sudah mendapatkan sertifikasi dari LP-POM MUI.

3. Transaksi dalam perdagangan tersebut tidak mengandung unsur gharar (penipuan), maysir (judi), dharar (bahaya), dzulm (aniaya/merugikan salah satu pihak, dan maksiat;

Dalam transaksi penjualan maupun dalam perekrutan member, PT. KLink selalu mengedepankan sikap profesionalitas. Member diwajibkan menjual produk sesuai dengan harga yang ada di katalog. Ketika mengajak seseorang atau calon pembeli yang biasa disebut prospek untuk pergi ke seminar, bahwa member harus mengatakan dengan jelas jika seminar yang didatangi adalah seminar dari PT. KLink, jadi tidak terjadi unsur penipuan. Tidak juga mengurangi hak orang lain yang ada di bawahnya (downline), juga tidak dzalim karena produk yang dijual sesuai dengan harga yang ada di katalog, sedangkan produk-produk yang dikonsumsi tersebut adalah halal yang mana tidak mengandung yang diharamkan seperti babi, khamr, dam lain sebagainya, selain itu juga berkhasiat untuk kesehatan, jadi tidak ada bahayanya (dharar).

4. Tidak ada kenaikan harga/biaya yang berlebihan (excessive mark up) sehingga merugikan konsumen karena tidak sepadan dengan kualitas/manfaat yang diperoleh;

Produk daripada PT. K-Link adalah produk impor, yang mana merek dan kualitasnya sudah dikenal demikian luas, sehingga harganya termasuk mahal, dan harganya tiap tahun bisa berubah.

5. Komisi yang diberikan perusahaan kepada anggota harus berdasarkan pada prestasi kerja nyata yang terkait langsung dengan volume atau nilai hasil penjualan barang atau jasa dan harus menjadi pendapatan utama mitra usaha dalam PLBS (Penjualan Langsung Berjenjang Syariah);

Banyak bonus atau komisi, keuntungan, bahkan reward yang ditawarkan oleh PT. K-Link sesuai dengan tingkat atau volume dari transaksi penjualan member, dan perekrutan calon member. Semakin banyak transaksi penjualan dan perekrutan yang dilakukan oleh member, semakin banyak komisi atau bonus, keuntungan, reward, serta pencapaian level yang semakin tinggi.

6. Bonus yang diberikan oleh perusahaan kepada anggota (mitra usaha) harus jelas jumlahnya ketika dilakukan transaksi atau akad sesuai dengan target penjualan barang dan jasa yang ditetapkan oleh perusahaan;

Dalam ketentuannya, PT. K-Link telah menetapkan ketentuan yang sangat jelas dan lengkap mengenai jumlah bonus, keuntungan, poin, dan tingkat atau level yang akan didapatkan oleh member PT. K-Link. 
Dalam hal tersebut sudah dijelaskan juga pada waktu training member.

7. Tidak boleh ada komisi/bonus secara pasif yang diperoleh secara reguler tanpa melakukan pembinaan dan atau penjualan barang dan jasa;

Misalnya member PT. K-Link telah melakukan penjualan produk setiap bulannya sampai bulan berikutnya, maka secara otomatis memperoleh bonus, keuntungan, dan reward dari PT. K-Link. Kenyataannya tingkatan atau level atasnya (upline) memperoleh penghasilan yang lebih besar daripada bawahannya (downline). Hal ini biasa disebut dengan insentif passive income, yang mana tidak harus bersusah payah untuk meningkatkan volume transaksi penjualan maupun usaha perekrutan calon member atau biasa yang disebut dengan prospek. Upline selalu diuntungkan dalam hal ini, karena tingkatannya lebih tinggi daripada downline-nya. Ketika semakin banyak transaksi penjualan dan perekrutan yang dilakukan oleh downline semakin besar pula komisi, maupun reward yang diperoleh upline. Yang jelas perbedaan fundamental dalam hal keuntungan yang diperoleh oleh upline selalu lebih besar ketimbang downline.

8. Pemberian komisi/bonus oleh perusahaan kepada anggota (mitra usaha) tidak menimbulkan ighra' (daya tarik luar biasa yang menyebabkan orang lalai terhadap kewajibannya demi melakukan hal-hal atau transaksi dalam rangka memperoleh bonus/komisi yang dijanjikan);

PT. K-Link menawarkan penghasilan meliputi bonus atau komisi, keuntungan, reward, bahkan fasilitas yang mewah bagi para membernya, sehingga bisa menyebabkan orang lalai karena berbagai hal yang ditawarkan tersebut sangat menggiurkan.

9. Tidak ada eksploitasi dan ketidakadilan dalam pembagian bonus antara anggota pertama dengan anggota berikutnya;

Adanya unsur ketidakadilan dalam pembagian komisis atau bonus, reward, dan lain sebagainya. Karena penghasilan upline selalu di atas daripada downline-nya.

10. Sistem perekrutan keanggotaan, bentuk penghargaan dan acara seremonial yang dilakukan tidak mengandung unsur yang bertentangan dengan dengan akidah. Syari'ah dan akhlak mulia, seperti syirik, kultus, maksiat, dan lain sebagainya;

Acara seremonial oleh PT. K-Link yang dilaksanakan pada setiap minggu sekali dihadiri oleh Dewan Pengawas Syariah (DPS), dan juga diberi pengajian ceramah (mauindhoh hasanah).

11. Setiap mitra usaha yang melakukan perekrutan keanggotaan berkewajiban melakukan pembinaan dan pengawasan kepada anggota yang direkrutnya; 
Multi Level Marketing dalam Tinjauan Hukum Islam (Studi Fatwa DSNMUI NOMOR: 75/DSN-MUI/VII/2009 Tentang Pedoman Penjualan Langsung Berjenjang Syariah)

Peran yang level atau tingkatannya paling atas (upline) PT. K-Link adalah membina, mengawasi, membimbing, dan membantu downlinenya

12. Tidak melakukan kegiatan money game.

PT. K-Link telah menerapkan sistem penjualan langsung dan berjejaring yang mana dengan penjualan ketika ada barang dan jasa yang diperjualbelikan. Akan tetapi sistem insentif passive income sebagaimana yang telah dipraktikkan oleh PT. K-Link menggunakan sistem piramida seperti yang banyak dipakai dalam money game. Dalam money game, bonus atau komisi bukan diperoleh dari omzet penjualan atau transaksi akan tetapi dari perekrutan member, semakin banyak orang yang direkrut untuk dijadikan member semakin banyak pula bonus perekrutan diperoleh, hingga orang yang terakhir tergabung akan kesulitan untuk mengembangkan bisnisnya, dan ini tidak sesuai dengan prinsip syari'ah.

Berdasarkan hal tersebut, Multi Level Marketing pada PT. K-Link belum memenuhi ketentuan hukum yang terdapat dalam fatwa DSN-MUI Nomor: 75/DSN-MUI/VII/ 2009 tentang Pedoman Penjualan Berjenjang Syariah. Diketahui bahwa insentif passive income yang diperoleh member dengan tingkat yang paling atas, dan penghasilan upline selalu lebih besar daripada downline-nya. Padahal downline sudah bersusah payah bekerja keras, sehingga menimbulkan kesan adanya ketidakadilan. Hal tersebut bertentangan dengan kaidah al ghunmu bi al ghurmi, yang artinya bahwa keuntungan itu sesuai dengan tenaga yang dikeluarkan atau resiko yang dihadapi. Dalam MLM tersebut, ada pihak-pihak yang paling dirugikan yaitu mereka yang berada pada tingkatan atau level-level bawah, padahal merekalah yang sebenarnya bekerja keras, bersusah payah untuk melakukan perekrutan anggota baru, tetapi keuntungannya yang menikmati adalah orang-orang yang berada pada level atas. Akan tetapi hal tersebut diterima dengan kerelaan (antarodhin) oleh member yang berada pada tingkat bawah (downline). Mereka saling rela dan tidak ada unsur keterpaksaan dalam hal pendapatan yang diterima lebih kecil daripada upline. Maka hal tersebut diperbolehkan dalam Islam.

\section{KESIMPULAN}

Dari beberapa uraian di atas dapat disimpulkan bahwa Multi Level Marketing Syariah yang mana telah dipraktikkan oleh masyarakat sebagaimana yang difatwakan oleh DSN-MUI Nomor: 75/DSNMUI/VII/2009 tentang Pedoman Penjualan Langsung Berjenjang Syariah hukumnya adalah boleh, dengan merujuk kepada hadis-hadis yang diuraikan sebelumnya bahwasanya dapat dijadikan sebagai hujjah atau pedoman hukum dan segala kegiatan bisnis yang menggunakan pedoman 
penjualan berjenjang diharuskan memenuhi berbagai ketentuan-ketentuan sebagaimana yang terdapat dalam fatwa DSN-MUI Nomor: 75/DSNMUI/VII/2009. DSN-MUI menggunakan dalil-dalil tersebut adalah sebagai landasan secara umum, karena tidak ada dalil yang spesifik terkait dengan Multi Level Marketing.

Berdasarkan hal-hal yang diuraikan sebelumnya, ada hal-hal penting yang perlu menjadi perhatian dalam permasalahan Multi Level Marketing Syariah, yaitu:

1. Masyarakat dihimbau untuk lebih selektif dalam memilih bisnis MLM, sehingga tidak terjebak dalam bisnis yang berkedok MLM yang ternyata dalam bisnis tersebut mengandung unsur money game yang mana sistemnya menggunakan skema piramida.

2. Dengan adanya fatwa DSN-MUI Nomor: 75/DSN-MUI/VII/2009, diharapkan perusahaan MLM baik yang mendapatkan sertifikat halal maupun tidak, dapat menjalankan bisnis tersebut sesuai dengan ketentuan-ketentuan syari'ah.

3. Bagi para pelaku bisnis MLM Syariah, diharapkan mampu menjalankan bisnis sesuai dengan prinsip dan ketentuan syariah, sehingga dapat menjauhkan dari hal-hal yang dapat merugikan diri sendiri maupun pihak lain. 
Multi Level Marketing dalam Tinjauan Hukum Islam (Studi Fatwa DSNMUI NOMOR: 75/DSN-MUI/VII/2009 Tentang Pedoman Penjualan Langsung Berjenjang Syariah)

\section{DAFTAR PUSTAKA}

Dewan Syariah Nasional dalam MLM, dalam http://www.e-syariah.com. Akses tanggal 10 November 2018.

Fatwa DSN-MUI Nomor: 75/DSN-MUI/VII/2009 tentang Pedoman Penjualan Langsung Berjenjang Syariah

Harefa, Andrias, Multilevel Marketing: Alternatif Karier dan Usaha Menyongsong Milenium Ketiga (Jakarta: Gramedia Pustaka Utama, 1999.

K. Lubis, Suhrawardi, Hukum Ekonomi Islam, Jakarta: Sinar Grafika, 2000.

Santoso, Benny, All About MLM: Memahami Lebih Jauh MLM dan Pernikperniknya, Yogyakarta: Andi, 2003.

Santoso, Singgih, Politik Multilevel Marketing dan Money Game di Indonesia, cet. ke-1, Yogyakarta: Duta Wacana University Press, 2000.

Yusuf, Tarmizi, Strategi MLM Secara Cerdas dan Halal, cet. ke-1, Jakarta: Elex Media Computindo. 